\title{
ANALYSIS OF GEOMETRIC FEATURES OF THE 316L STEEL SURFACE AFTER DIFFERENT SURFACE TREATMENT METHODS
}

\author{
Mariusz Kłonica ${ }^{1}$ \\ ${ }^{1}$ Department of Production Engineering, Faculty of Mechanical Engineering, Lublin University of Technology, 36 \\ Nadbystrzycka St., 20-618 Lublin, Poland, e-mail: m.klonica@pollub.pl
}

\section{ABSTRACT}

The paper presents the selected results of surface quality. The selected 2D and 3D surface roughness parameters are analyzed. An intensive development of various surface topography measuring techniques allows the prediction of the functional attributes of the surface and also evaluation of its quality. The results of the evaluation of surface roughness is highly influenced by their measurement strategy. Finally, some general conclusions are given.

KEYWORDS: surface layer, surface roughness, 316L steel

\section{ANALIZA CECH GEOMETRYCZNYCH POWIERZCHNI STALI 316L PO RÓŻNYCH SPOSOBACH OBRÓBKI}

\section{STRESZCZENIE}

W pracy przedstawiono wybrane wyniki badań jakości powierzchni. Analizie poddano wybrane parametry chropowatości powierzchni 2D oraz 3D. Intensywny rozwój różnych technik pomiaru topografii powierzchni pozwala na przewidywanie właściwości funkcjonalnych powierzchni oraz ocenę jej jakości. Na wyniki oceny parametrów chropowatości duży wpływ ma strategia ich pomiaru. Pracę zakończono wnioskami.

StOWA KLUCZOWE: warstwa wierzchnia, chropowatość powierzchni, stal 316L

\section{Introduction}

Nowadays, a geometric structure of surface is quite important because of the following significant reasons: functional, exploitative and esthetic. Recently, an intensive development of various metrology techniques for a surface layer [1-4] gives the opportunity to predict the functional and the exploitative attributes of the surface. Hence, the measurements of that kind are made in accordance to the accurate evaluation of surface topography and surface quality after the treatment. A geometric structure of material surface consists of three primary elements i.e. shape, waviness and roughness. Surface roughness is a surface quality feature and it can be described by quantitative indicators such as $2 \mathrm{D}$ roughness parameters (profile method: contact or contactless) and 3D roughness parameters (stereometric method). Many scientific studies show that the measurement strategy is crucial to properly evaluate the values of above mentioned parameters [5-7]. Moreover, filtration is one of the most significant features in the measurement of surface roughness parameters. Because of its importance to topography measurements, filtration has become a subject of many standards [8-11] and studies [12-16]. 
Furthermore, analyzing the selected attributes of a geometric structure of surface, especially surface roughness parameters, plays a very important role $[2,4,12-15]$ in preparing the surface layer to adhesive technology. Adhesive attributes of a surface layer are widely used in various kinds of material couplings applied in the industry. Therefore, a proper preparation of a surface layer is the important factor of making adhesive joints. Study of surface layer properties is an interesting subject of surface engineering.

\section{Methodology of the study}

The variants of surface layer preparation for the specimens made from $316 \mathrm{~L}$ steel are given in Table 1. Four variants of specimens were prepared. Each specimen had the dimensions as follows: $100 \times 25 \times 1.5 \mathrm{~mm}$ (length, width, thickness). Then all samples were degreased with Loctite 7061 degreasing agent. Two stages of cleaning process were conducted. Firstly, the specimens were rinsed using the degreasing agent and then wiped with a paper towel (both activities were performed twice). Secondly, the specimens were rinsed with Loctite 7061 and left for evaporation. The surface treatment using both nonwoven fabric and coated abrasive tool (P100 and P320) was conducted manually.

Table 1. Variants of specimens preparation

\begin{tabular}{|r|r|}
\hline \multicolumn{1}{|c|}{ Variant } & Treatment method \\
\hline T1 & Before the treatment \\
\hline T2 & After the treatment using nonwoven fabric P80 \\
\hline T3 & After the treatment using coated abrasive tool with granularity P100 \\
\hline T4 & After the treatment using coated abrasive tool with granularity P320 \\
\hline
\end{tabular}

The chemical composition of $316 \mathrm{~L}$ steel (which was the material for making specimens) is given in Table 2 - elaborated in accordance to material certificate.

Table 2. Chemical composition of $316 \mathrm{~L}$ steel (according to material certificate)

\begin{tabular}{|l|r|r|r|r|r|r|r|r|r|}
\hline \multicolumn{10}{|c|}{ 316L steel } \\
\hline Element & $\mathrm{C}$ & $\mathrm{Si}$ & $\mathrm{Mn}$ & $\mathrm{P}$ & $\mathrm{S}$ & $\mathrm{Ni}$ & $\mathrm{Cr}$ & $\mathrm{Mo}$ & $\mathrm{N}$ \\
\hline Content, \% & 0,011 & 0,54 & 1,03 & 0,040 & 0,001 & 10,18 & 16,71 & 2,05 & 0,020 \\
\hline
\end{tabular}

Moreover, the selected properties of $316 \mathrm{~L}$ steel are shown in Table 3 - elaborated in accordance to material certificate.

Table 3. Selected properties of $316 \mathrm{~L}$ steel (according to material certificate)

\begin{tabular}{|r|r|}
\hline \multicolumn{2}{|c|}{ 316L steel } \\
\hline Tensile strength Rm [MPa] & 592 \\
\hline Conventional yield point Rp0,2 [MPa] & 290 \\
\hline Hardness [HV] & 148 \\
\hline
\end{tabular}

The measurements of surface roughness were conducted using T8000 RC-120-400 equipment produced by Hommel-Etamic. The device is dedicated to measure contour, roughness and 3D topography and it is equipped with a measurement tip which has a radius of $2 \mu \mathrm{m}$. The length of the elementary section was adjusted according to the literature [3]. Subsequently, Keyence VHX-5000 microscope was used during the research in order to show the microscopic views of the surfaces after different treatment methods. 
The measurements of 2D surface roughness parameters (for all variants) were repeated minimum seven times. The average values are compared in tables.

\section{Experimental results}

The selected surface roughness profiles for $316 \mathrm{~L}$ steel specimens and Abbott-Firestone curve (bearing area curve) are given in Table 4 for all variants of treatment. The specimens' surfaces were cleaned in advance of measuring. It was noticed that treatment using coated abrasive tools and nonwoven fabric let the analyzed specimens' surfaces to be developed.

Table 4. Surface roughness profiles and Abbot-Firestone curve

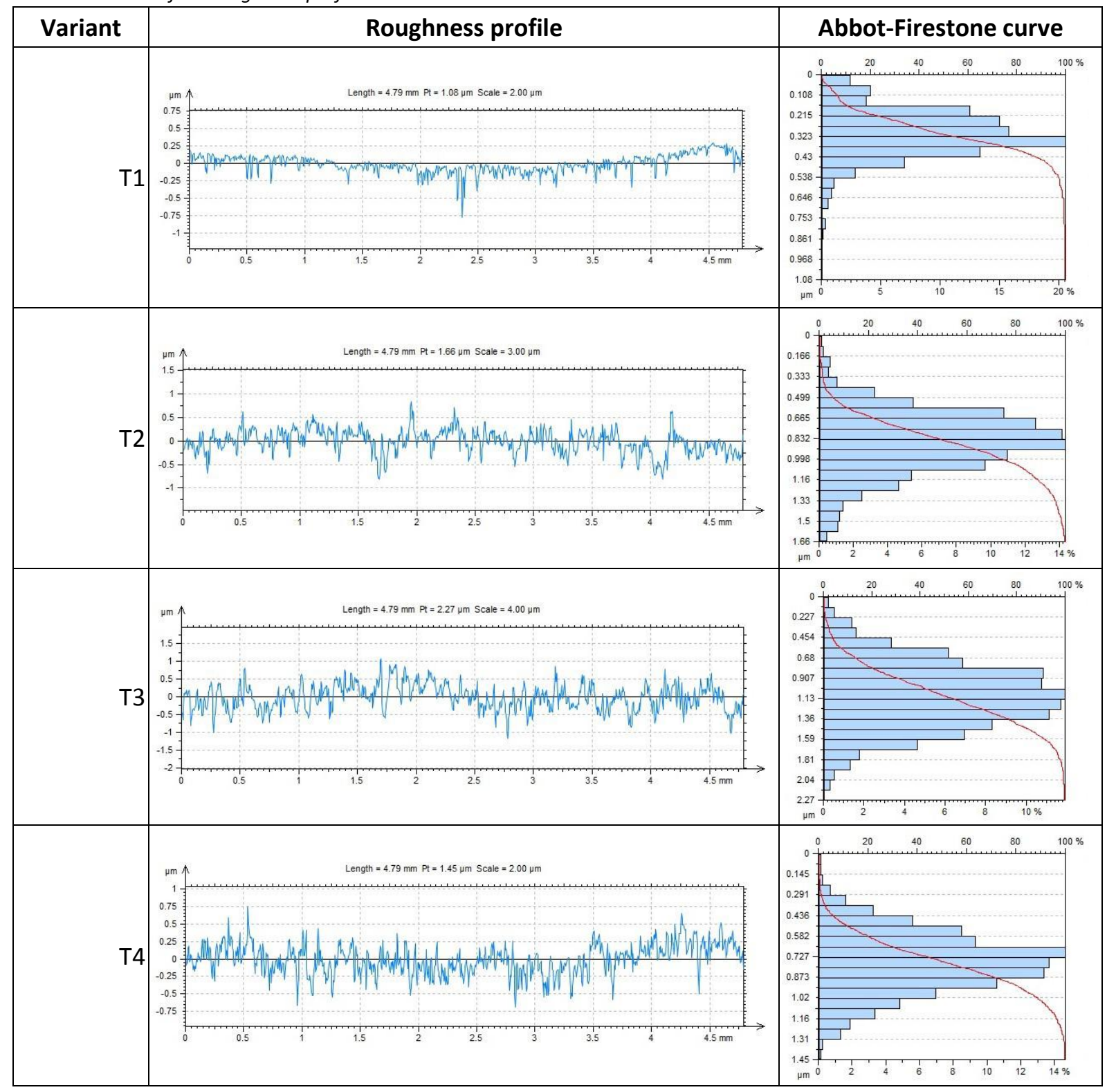

The specific grooves presenting kinematic-geometric imaging of tools were observed after the treatment using coated abrasive tools (with granularity P100 and P320) and nonwoven fabric P80 for the specimens made of $316 \mathrm{~L}$ steel.

Furthermore, the topography of the surfaces after different methods of specimens preparation is shown in Table 5. 
Table 5. Isometric views of the surfaces after different methods of specimens preparation

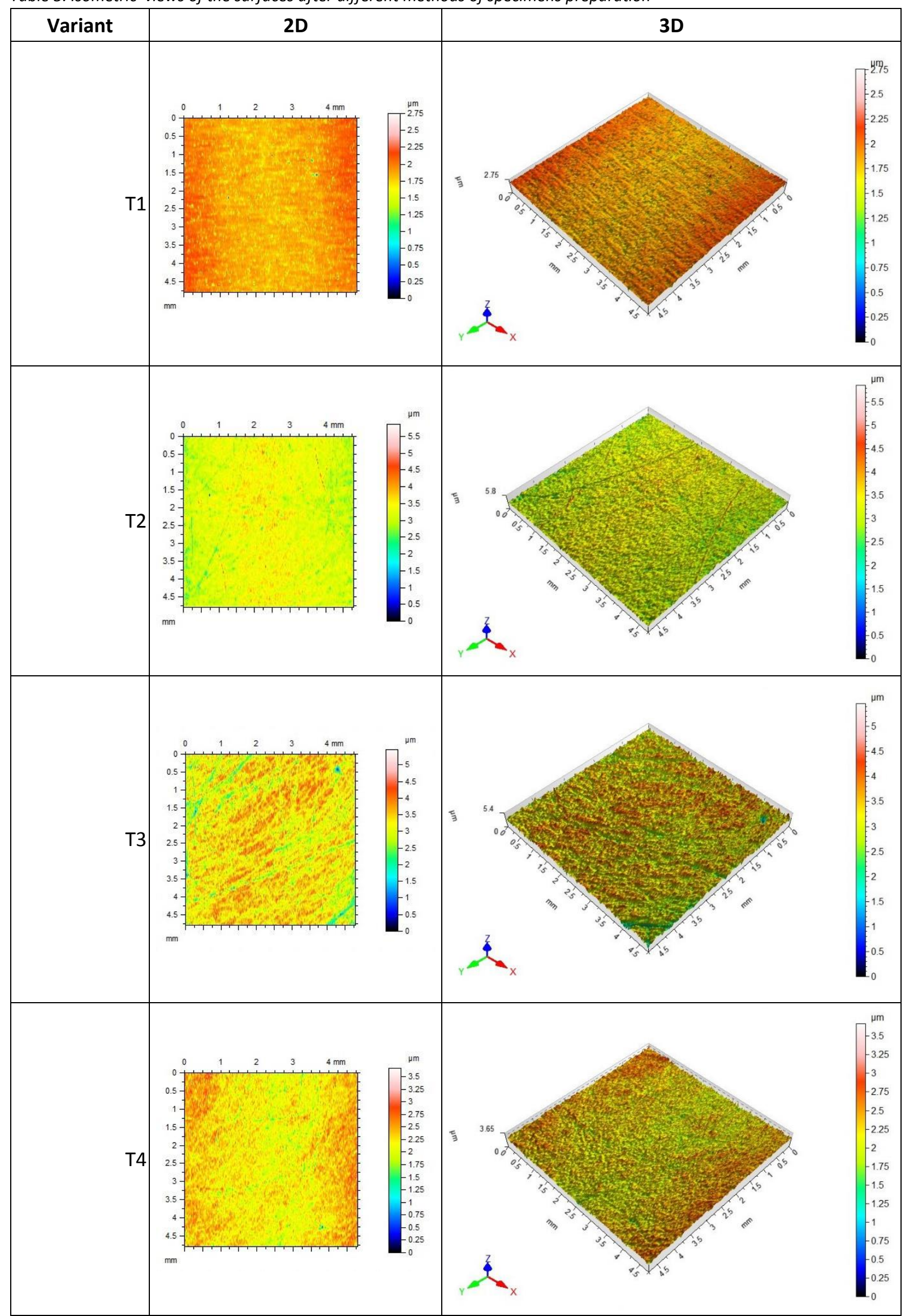


The views of 2D images and 3D isometric maps are compared in Table 5. As it can be seen in the presented maps of surface topography there are some traces on the specimens' surfaces which are typical after the treatment.

Moreover, the selected 3D surface roughness parameters for all analyzed variants of the treatment are given in Table 6.

Table 6. 3D surface roughness parameters for $316 \mathrm{~L}$ steel

\begin{tabular}{|r|r|r|r|r|r|r|}
\hline \multirow{2}{*}{ Variant } & \multicolumn{7}{|c|}{ 3D parameters $[\mu \mathrm{m}]$} \\
\cline { 2 - 7 } & Sq & \multicolumn{1}{c|}{ Sp } & \multicolumn{1}{c|}{ Sv } & \multicolumn{1}{c|}{ Sz } & \multicolumn{1}{c|}{ Sa } & \multicolumn{1}{c|}{ St } \\
\hline T1 & 0,126 & 0,869 & 1,89 & 2,75 & 0,0916 & 2,75 \\
\hline T2 & 0,268 & 2,63 & 3,23 & 5,86 & 0,21 & 5,86 \\
\hline T3 & 0,441 & 2,18 & 3,28 & 5,45 & 0,344 & 5,45 \\
\hline T4 & 0,232 & 1,42 & 2,25 & 3,67 & 0,182 & 3,67 \\
\hline
\end{tabular}

Based on the conducted research it can be noticed that all analyzed surface roughness parameters for T2-T4 variants are higher than for T1 variant. The biggest increase of analyzed surface roughness parameters is visible for both $\mathrm{T} 2$ and $\mathrm{T} 3$ variants.

The selected 2D surface roughness parameters for the specimens made of $316 \mathrm{~L}$ steel after different methods of specimens preparation are given in Table 7. The dispersion of the results is characterized by standard deviation. The following $2 \mathrm{D}$ surface roughness parameters were analyzed: $\mathrm{Rt}-\mathrm{a}$ total height of roughness profile, $\mathrm{Rz}$ - a maximum height of roughness profile, $\mathrm{Rp}-$ a maximum height of roughness profile peak and $\mathrm{Ra}$ - arithmetic average of roughness profile ordinates. The research parameters are presented in accordance to standards [8-11].

Table 7. Selected 2D surface roughness parameters

\begin{tabular}{|r|r|r|r|r|r|}
\hline \multicolumn{2}{|c|}{ Variant } & Rt $[\mu \mathrm{m}]$ & $\mathbf{R z}[\mu \mathrm{m}]$ & $\mathbf{R p}[\mu \mathrm{m}]$ & Ra $[\mu \mathrm{m}]$ \\
\hline \multirow{2}{*}{$\mathrm{T} 1$} & Average value & 0,760 & 0,475 & 0,107 & 0,054 \\
\cline { 2 - 6 } & Standard deviation & 0,021 & 0,002 & 0,004 & 0,003 \\
\hline \multirow{2}{*}{ T2 } & Average value & 1,54 & 1,17 & 0,607 & 0,159 \\
\cline { 2 - 6 } & Standard deviation & 0,029 & 0,021 & 0,006 & 0,008 \\
\hline \multirow{2}{*}{$\mathrm{T} 3$} & Average value & 1,88 & 1,59 & 0,810 & 0,242 \\
\cline { 2 - 6 } & Standard deviation & 0,032 & 0,028 & 0,011 & 0,014 \\
\hline \multirow{2}{*}{ T4 } & Average value & 1,27 & 0,988 & 0,479 & 0,136 \\
\cline { 2 - 6 } & Standard deviation & 0,026 & 0,023 & 0,008 & 0,011 \\
\hline
\end{tabular}

Based on the conducted research it can be inferred that surface roughness parameters for T2-T3 variants are higher than in case of $\mathrm{T} 1$ variant. The biggest increase of Rz parameter is noticeable for T3 variant and it equals over $300 \%$.

The pictures of specimens' surfaces taken with magnification of 100 and 1000 times are shown in Table 8. 
Table 8. Pictures of specimens' surfaces

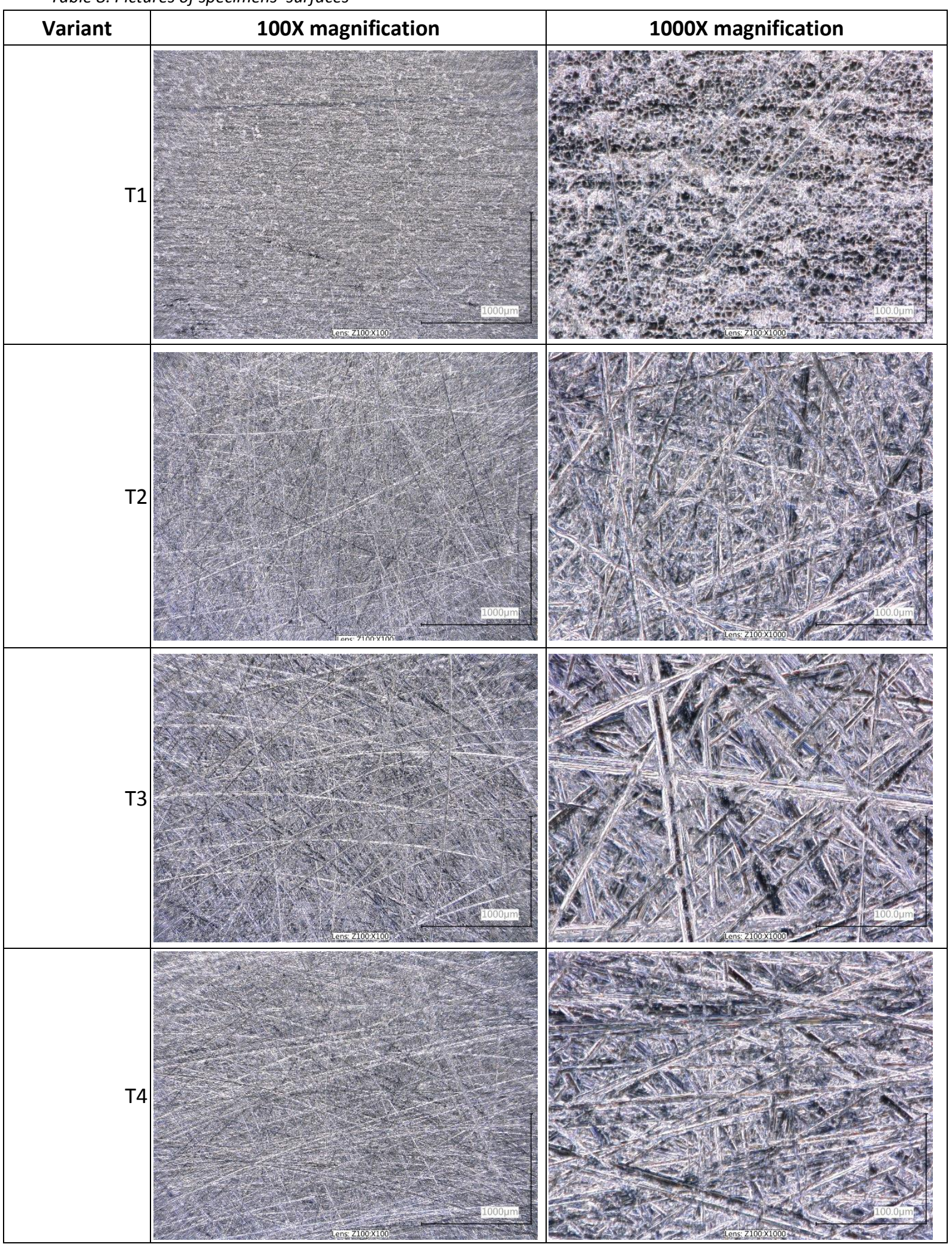

After the deeply analysis of the pictures it can be concluded that surface treatment using nonwoven fabric as well as using coating abrasive tools (with different granularity) allows to remove physisorption layer efficiently and geometrically develop the surface. 


\section{Conclusions}

Based on the conducted research and the analysis of the results it may be concluded as follows:

1. The surface treatment using coated abrasive tools (with granularity P100 and P320) and nonwoven fabric P80 let the analyzed surface to be efficiently developed.

2. The biggest increase of the analyzed 3D surface roughness parameters is observed for $\mathrm{T} 2$ and $\mathrm{T} 3$ variants relative to $\mathrm{T} 1$ specimens.

3. For the Rz surface roughness parameter (2D parameter) the biggest increase is observed in case of T3 variant relative to T1 variant. The increase equals over $300 \%$.

\section{References}

[1] S. Adamczak, Pomiary geometryczne powierzchni. Zarysy kształtu, falistość i chropowatość. Warszawa, WNT, 2008.

[2] M. Blicharski, Inżynieria powierzchni. Warszawa, WNT, 2009.

[3] Z. Humienny (red.), Specyfikacje Geometrii Wyrobów (GPS) - wykład dla uczelni technicznych. Oficyna wydawnicza PW, 2001.

[4] B. Kamieńska-Krzowska, M. Kłonica, "Rola strategii pomiarów topografii powierzchni w ocenie wybranych parametrów chropowatości," Mechanik, nr 8-9, 138-145, 2014.

[5] M. Wieczorowski, A. Cellery, J. Chajda, Przewodnik po pomiarach nierówności powierzchni czyli o chropowatości i nie tylko. Politechnika Poznańska, Poznań 2006.

[6] M. Wieczorowski, "Podstawy teoretyczne filtracji morfologicznej w pomiarach chropowatości powierzchni, " Archiwum Technologii Maszyn i Automatyzacji, Vol.29 nr 4, 41-49, 2009.

[7] A. Zaborski, "Komputeryzacja pomiarów błędów kształtu i stereometrii przedmiotów walcowych," Mechanik, nr 11, 828-832, 2010.

[8] PN-EN ISO 4288:1997, Wymagania geometryczne wyrobów. Struktura geometryczna powierzchni. Zasady i procedury oceny struktury geometrycznej powierzchni metodq profilowq.

[9] PN-EN ISO 11562:1998, Specyfikacje geometrii wyrobów. Struktura geometryczna powierzchni. Metoda profilowa. Charakterystyki metrologiczne filtrów z korekcja fazy.

[10] PN-EN ISO 13565-1:1999, Specyfikacje geometrii wyrobów. Struktura geometryczna powierzchni. Metoda profilowa. Powierzchnie o warstwowych właściwościach funkcjonalnych. Filtrowanie i ogólne warunki pomiaru.

[11]PN-EN ISO 4287:1999/A1:2010P, Specyfikacje geometrii wyrobów. Struktura geometryczna powierzchni: metoda profilowa. Terminy, definicje i parametry struktury geometrycznej powierzchni.

[12] M. Kłonica, J. Kuczmaszewski, M. Kwiatkowski, J. Ozonek, "Polyamide 6 surface layer following ozone treatment," International Journal of Adhesion and Adhesives, 64, 179-187, 2016.

[13] J. Kuczmaszewski, I. Zagórski, "Badania chropowatości po frezowaniu stopów magnezu AZ31 i AZ91HP," Mechanik, nr 12, 999-1004, 2012.

[14] J. Matuszak, K. Zaleski, "Wpływ warunków obróbki szczotkowaniem na chropowatość powierzchni przedmiotów wykonanych ze stopu aluminium," Mechanik, nr 8-9, 509-516, 2014.

[15] A. Skoczylas, "Analiza porównawcza procesu cięcia wiązką laserową i strumieniem wodnościernym," Advances in Science and Technology, nr 8, 121-128, 2011.

[16] W. Zielecki, P. Pawlus, R. Perłowski, A. Dzierwa, "Surface topography effect on strength of lap adhesive joints after mechanical pretreatment, " Archives of Civil and Mechanical Engineering, 13, nr 2, 175-185, 2013. 